\title{
Obituaries
}

\section{FRANCIS DEREK THOMAS}

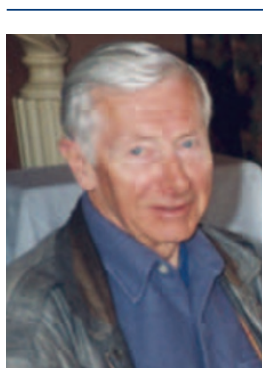

Derek Thomas died on 7 October 2007 aged 81. He was born in Hyde on 16 April 1926 and moved to Lancaster in the 1930s. After leaving Lancaster Royal Grammar School he entered the army, where his interest in dentistry was fostered when he was treated by a dentist who impressed him. By the time Derek completed his officer training the war in Europe was over and he was sent to Trieste with the army of occupation. Here he developed severe tonsillitis and was sent to convalesce in the Alps, where he discovered skiing, which became the love of his life.

After being demobbed Derek achieved the necessary qualifications to attend the Turner Dental School at Manchester University, married in 1951 and started a family. While at university he was also an officer in the Territorial Army Intelligence Corps. He qualified in 1954, gained locum experience around Britain and started a successful dental practice in Barrow-in-Furness in 1960. Derek was a passionate believer in safe dental anaesthesia and lectured nationally for SAAD. He was also a strong supporter of the BDA.

In 1966 the family moved to Plymouth where Derek established another dental practice. Here he developed a passion for sailing, gained an Ocean Yachtmaster Certificate and organised and taught a series of navigational courses. He also developed a strong interest in scuba diving and published several articles on diving and navigation.
In 1975 Derek was appointed as the Area Dental Officer for Gwynedd. While in North Wales he furthered his interest in epidemiology and published research validating the importance of fluoridation in dental health. He also bought an apartment in the French Alps, where he spent many happy times with his family, became a qualified ski instructor and also taught his children and grandchildren to ski.

Following retirement Derek suffered a near fatal heart attack in France in 1993. Even when told that he would never ski again, his courage and determination ensured that he continued skiing until having a severe stroke in 2005. Despite extreme disability he continued to enjoy a less energetic but fulfilling quality of life for almost three years.

Derek died peacefully at home in his sleep leaving a widow, three children and six grandchildren. He is sadly missed.

Margaret Thomas

\section{WILLIAM ROWLAND THOMAS}

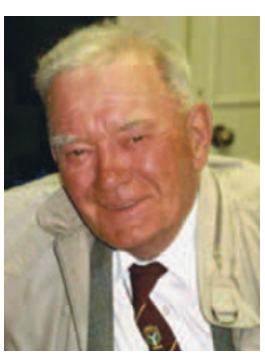

$\mathrm{Mr}$ William Rowland Thomas (known as Rowland) died on 12 August 2008, aged 82. He was the younger son of the late Rev. Jack Thomas and the late Mrs Marion Thomas, and brother of the late Ieuan Thomas, also a dentist.

Rowland and Ieuan were brought up in Haverfordwest and spent much time on the Pembrokeshire coast, cycling the eight miles to Little Haven. As boys both were strong swimmers, and at least one person owes their life to the brothers, who rescued a swimmer in difficulty. After the war, Rowland and his brother studied dentistry at Guy's Hospital in London, and subsequently set up dental practice together in Worcester. Rowland then served in the army in Cyprus for several years before returning to south Wales where he looked after his elderly mother in Ystrad Rhondda (where his maternal grandfather had been treasurer to the town council), and practised dentistry at Goodwin \&t Partners in Porth until his retirement.

Rowland never married, but spent many holidays with his brother's family in Norfolk and in France. He was a keen golfer and Treasurer of the senior section of the Penrhys Golf Club. He was a thoughtful and generous man who always took an interest in others around him and gave generously to charitable causes. In latter years he developed diabetes and had a leg amputated due to infection, and despite much time in hospital and subsequently living on his own with this disability, he was always upbeat and never complained. Rowland was a greatly liked and respected member of the local community and will be remembered with great affection by family and friends.

The funeral took place on Friday 22 August at Dewi Reynolds' Chapel of Rest in Treorchy. Rowland wished to be subsequently interred with family in Haverfordwest.

Rhodri Thomas 